\title{
Business Model Innovation with Design Thinking Approach at Bumdes Pagerwangi
}

\author{
Reni Wijayanti ${ }^{1}$, Nanda ravenska ${ }^{2}$, Adhika B Nugroho ${ }^{3}$ \\ Politeknik STIA LAN Bandung
}

\{reni.wijayanti@poltek.stialanbandung.ac.id\}

\begin{abstract}
Villages have the opportunity to develop the community's economy, one of which is by managing BUMDes (Village Owned Enterprises). The number of BUMDes in West Java in 2020 was ranked fourth BUMDes with the highest number of BUMDes, which was 6,423. One of the regencies in West Java is West Bandung Regency (KBB), where $\mathrm{KBB}$ consists of 16 sub-districts and 165 villages). KBB has many potential resources. In fact, in developing BUMDes there are still obstacles that need to be overcome to be able to achieve the goals of BUMDes. Some of the problems that usually occur are communication, business unit management, lack of human resources, less than optimal utilization of potential village resources, and lack of community participation. As happened to one of the BUMDes in KBB, namely the BUMDes of Pagerwangi Village. The implementation of design thinking can build the innovation of the Bumdes Pagerwangi business model by providing added value to the value proposition elements, key activities and key resources. Bumdes Pagerwangi can implement improvements to systems within its organization first and then apply business model innovations starting with 3 priority BMC elements followed by 6 other elements customer segments, channels, customer relationships, revenue streams, key partners, and cost structure.
\end{abstract}

Keywords: Village; BUMDes; Design Thinking; Business Model Canvass.

\section{Introduction}

The growth of economic development in the village is one of the factors that encourage the growth of national economic development the growth of economic development is the growth of the population's per capita income. Currently, the village is the spearhead of development and improvement of community welfare. In order to support the growth and programs of the village government, the central government provides support in the form of channeling village funds. Referring to Law No. 6 of 2014, village funds are sourced from the State Revenue and Expenditure Budget (APBN).

Village funds are allocated for villages that are transferred through the Regency/City Regional Revenue and Expenditure Budget. The central government annually budgets a fairly large village fund where from 2015-2021 the number of village funds budgeted increases until 2021 to Rp 72 trillion. Looking at the results of the Central Government's evaluation in the implementation of the 2015-2017 village fund distribution, village funds have proven to have produced facilities/infrastructure that are beneficial to the community and improve the quality of life of rural communities such as the construction of village roads, bridges, construction of clean water channels, drainage and irrigation, establishment of early childhood education. , 
making wells, village markets, boat moorings, polindes and posyandu [1]. Villages have the opportunity to develop the community's economy, one of which is by managing BUMDes (Village Owned Enterprises).

BUMDes are village economic institutions/agencies that are legal entities formed and owned by the Village Government, managed economically independently and professionally with all or most of the capital being separated village assets [2]. BUMDes was formed with the aim of obtaining profits to strengthen Village Original Income (PADes), promote the village economy, and improve the welfare of rural communities.

BUMDes manages village economic assets and resources by involving village communities using a self-management pattern, namely employing local workers, and utilizing local raw materials in the village. The number of BUMDes has increased every year [3]. Based on data from the Ministry of Villages, Development of Disadvantaged Regions and Transmigration (PDTT), until 2021 the number of BUMDes is 51,134 [4].

The number of BUMDes in West Java in 2020 was ranked fourth BUMDes with the highest number of BUMDes, which was 6,423. One of the regencies in West Java is West Bandung Regency (KBB), where KBB consists of 16 sub-districts and 165 villages). KBB has many potential resources. Based on data from the Village Community Empowerment Service, there are 130 Bumdes out of 165 villages in KBB.

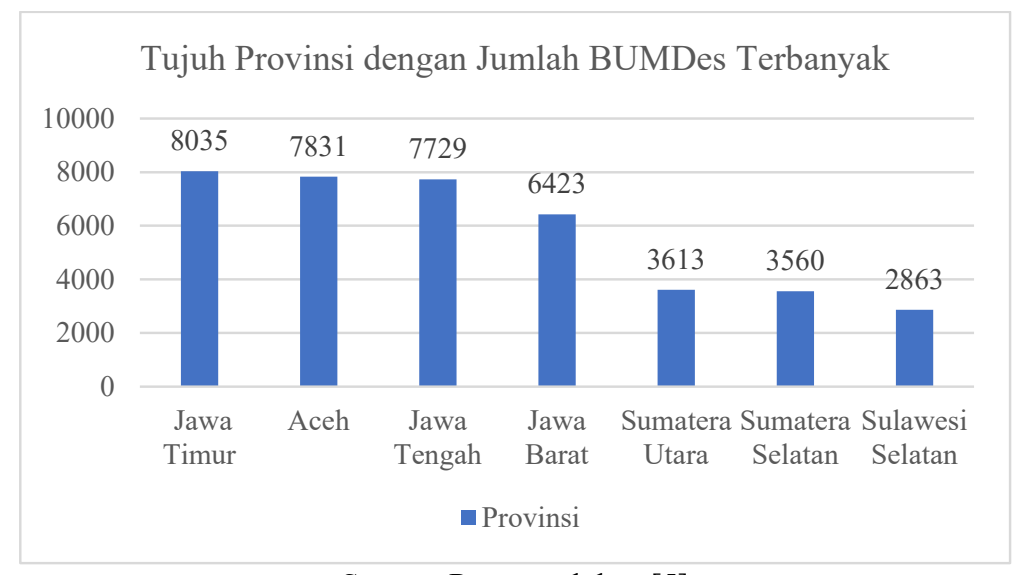

Source: Processed data [5]

In fact, in developing BUMDes there are still obstacles that need to be overcome to be able to achieve the goals of BUMDes. Some of the problems that usually occur are communication, business unit management, lack of human resources, less than optimal utilization of potential village resources, and lack of community participation. As happened to one of the BUMDes in KBB, namely the BUMDes of Pagerwangi Village.

The BUMDes of Pagerwangi Village already has two types of businesses running, including the futsal field and the BUMDes Mart. Both of these businesses have generated a fairly good turnover, but the profits obtained are still small, so they have not been able to make a large contribution to PADes. The success of BUMDes in achieving the goal of prospering the village is one of the things that requires innovation, creation and cooperation between village officials and the community. 
This study aims to assist the BUMDes of Pagerwangi Village in designing innovative business models using the design thinking method. Design Thinking is very essential with humans as the center of the innovation process which emphasizes observation, collaboration, fast learning, visualization of ideas, rapid concept prototyping and business analysis, which greatly influence innovation and business strategy [6]. Design Thinking is a framework for a human-centered approach to strategic innovation in value creation and is able to express a collaborative and multidisciplinary perspective that makes thinking and processes real, leading to innovative business solutions [7].

\section{Literature Review}

\subsection{Business Model Canvas}

Business model canvas (BMC) is a tool to translate concepts, consumers, infrastructure and company finances in the form of important elements contained in a business model. This business model was first introduced by Alexander Osterwalder in his book entitled Business Model Generation. BMC divides the essentials into clear foci. This makes it easier for businesspeople in various aspects and can be applied by companies both large and small scale.

There are nine important elements to assist in determining the company's work system as well as checking whether the company's activities are running according to the system.

a. Value Proposition

Value proposition is the selling value of products/services. The value is to attract consumers to prefer our products/services over those of competitors. Value prepositions are useful for knowing whether our business is selling what consumers really need and ascertaining whether our products provide solutions to customer problems.

b. Customer Segment

In this element, we group our customers based on static (such as demographic, geographic, etc.) and/or dynamic (such as psychographic) attributes..

c. Customer Relationship

Next in this customer relationship element is how to understand consumers and approach customers. There are many ways how to approach and interact with customers either directly or through the media.

d. Channels

Channel is a meeting place for sellers and consumers. Sales channels can be in the form of retail stores, stores owned by wholesalers, or through online.

e. Key Activities

Key activities are business activities carried out in order to achieve the value proposition.

f. Key Resources

Business actors need the right resources to support business activities. Examples of key resources such as facilities, facilities, buildings or rooms, vehicles, electricity, human resources, etc..

g. Key Partners

In running a business, we also need a working partner who supports us to achieve our business goals.

h. Cost Structures

Cost structure is a financial scheme that finances business operations. 
i. Revenue Streams

Every business needs revenue streams to keep it running its daily activities. Revenue stream is a source of company income from various sources, such as sales proceeds, dividends and so on.

\subsection{Design Thinking}

Defines Design Thinking

Design thinking is a tool used to solve problems, shape and design a problem. In the design thinking process using a human-centered approach (human-centered), originating and aimed at humans or if it is associated with business innovation, namely customers and consumers (endusers) of the products or services produced. Using design thinking can be used in strategic innovation and value creation. According to Idris Motee (2013), design thinking has several basic principles including:

a. Action-oriented, design thinking leads more to a learning by doing approach. So that it encourages direct interaction with the community and discovers various things.

b. Accustomed to change, design thinking is more likely to use new ways to solve a problem.

c. Human-centric, design thinking focuses on the needs of the customer or end-user

d. Integrated with future goals.

e. A dynamic and constructive process, design thinking is an iterative process, generating and applying insights and knowledge to ever-changing goals. On prototyping resistant, produce tangible results.

f. Put forward empathy.

g. Reducing risk by considering factors in technology, market, competitors and supply chain.

h. Creating meaning. Design thinking expresses the information needed to form and socialize meaning.

i. Takes creative endeavors to the next level.

j. Competitive logic for business strategy.

\section{Design Thinking as a Business Innovation Tool}

According to Law no. 19 of 2002, innovation is research, development, and or engineering activities carried out with the aim of developing the practical application of new scientific values and contexts, or new ways to apply existing science and technology into products or production processes.

Innovation in business aims to reinvent new business models and meet market needs. In general, innovation in business is to find solutions with technology and find new markets. In the search process to find the solution for an innovation, the design thinking method is used. With design thinking that focuses on humans, you are able to collaborate and make thoughts and processes come true and produce innovative business solutions.

Phases in Design Thinking

There are five phases of design thinking according to the Hasso-Plattner Design Institute at Stanford (d.school). The five phases of design thinking consist of Empathize, Define, Ideate, Prototype, and Test.

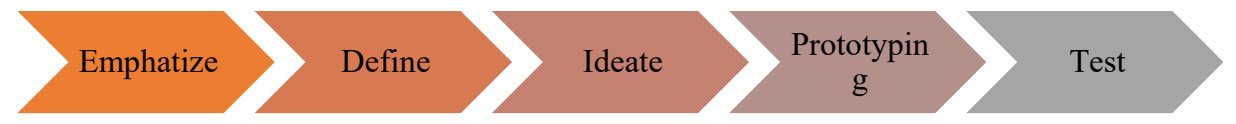


a. Emphatize

In the empathize phase, the goal is to gain an empathic understanding of the problem to be solved by approaching the customer. The activities carried out are identifying the wants and needs of customers. This can be done by directly meeting customers, conducting interviews and can also act as if you are a customer.

b. Define

The results obtained from the first phase are then analyzed and determined the core problem to be solved. This phase will make it easier for the next process because you already know the problems felt by the customer.

c. Ideate

The third phase is the process of generating ideas to solve customer problems. The ideas that arise will be collected first, then these ideas will be tested or brainstormed to determine the best ideas that are most likely to solve the problem..

d. Prototyping

In the fourth phase, realizing the ideas that have been selected. The result can be a product or other tangible thing.

e. Test

The last phase is testing the prototype by the team itself or involving other parties. It is hoped that from the test results, good feedback will be obtained for the improvement and refinement of the prototype.

\section{Research Method}

This research uses descriptive qualitative research method. Qualitative research is research that aims to gain a deep understanding of human and social problems, not to describe the surface of a reality. Research with a qualitative approach emphasizes the analysis of the process of inductive thinking processes related to the dynamics of the relationship between observed phenomena, and always uses scientific logic (Gunawan, 2015).

To build an innovative Business Model, researchers use Design Thinking as an approach and process in gathering information that involves users. Design Thinking basically has five stages, but in this study, the researcher limited it to the ideate stage. Empathize is the process of understanding and empathizing with users. In the define stage, the researcher unpacks and synthesizes the findings from the empathy stage and provides meaningful insights from the user's point of view. In the Ideate stage, researchers form ideas in the form of a business model which are spread into nine elements of the business model canvas.

This study uses primary and secondary data. According to Sugiyono (2014), primary data is data that refers to information obtained from informants of the research object directly, relating to the specific objectives of the study, namely answering the problem formulation. Researchers obtained primary data through interviews regarding the Design Thinking process, and the preparation of nine elements in compiling the Business Model Canvas. The interviews conducted in this study were semi-structured interviews, the purpose of which was to find problems more openly and freely where the interviewees were asked for their opinion or feedback along with their ideas.

In addition, researchers also made direct observations. While secondary data, researchers get a variety of literature. According to Sugiyono (2014), secondary data is data that refers to information obtained indirectly by researchers, the results are obtained from literature studies from previous research journals, knowledge books and other literature and the internet. 


\section{Research Result and Discussion}

\subsection{Design Thinking Stage}

a. Empathize

At this stage, the researcher identified the needs of the Pagerwangi BUMDes through interviews. Currently, Bumdes Pagerwangi has 2 business units that have been running for about 2 years, namely futsal field rentals and minimarkets. Futsal field rental can be said to be quite good by setting a relatively inexpensive rental price and the absence of similar facilities in the surrounding area. While the Bumdes Minimarket has been equipped with a recording and bookkeeping system that has been integrated into the available computer which is the assistance of other parties.

Although the two business units have been running well, Bumdes Pagerwangi needs to develop and add business units that are running to increase the income of Bumdes Pagerwangi so that they can then provide benefits to the village community. Currently, the Bumdes manager consists of 3 people who are also assisted by additional human resources who directly serve customers.

b. Define

At this stage, the researcher identified the needs of the Pagerwangi BUMDes through interviews. Currently, Bumdes Pagerwangi has 2 business units that have been running for about 2 years, namely futsal field rentals and minimarkets. Futsal field rental can be said to be quite good by setting a relatively inexpensive rental price and the absence of similar facilities in the surrounding area. While the Bumdes Minimarket has been equipped with a recording and bookkeeping system that has been integrated into the available computer which is the assistance of other parties.

Although the two business units have been running well, Bumdes Pagerwangi needs to develop and add business units that are running to increase the income of Bumdes Pagerwangi so that they can then provide benefits to the village community. Currently, the Bumdes manager consists of 3 people who are also assisted by additional human resources who directly serve customers.

c. Ideate

At this stage, the researcher collects and compiles information from the interviews as a support in creating a business model that can answer the expectations of the Pagerwangi Bumdes. Based on the results of the interviews, the researchers found that there are aspects such as Value Proposition, Key Activities, and Key Resources in the business model that need to be the main focus in the development stage of the bumdes itself.

Dengan melakukan proses empathize, define, dan ideate, peneliti dapat menemukan dan mengembangkan model bisnis sesuai dengan keinginan dan harapan Bumdes Pagerwangi. Model bisnis berbasis kanvas akan menangkap keseluruhan aspek yang perlu diimplementasikan agar dapat meningkatkan kinerja bumdes

\subsection{Business Model Canvas-Based Innovation Business Model with Development from Design Thinking}

To make the bumdes grow, the researcher identified the business model through the nine elements of the business model canvas and made improvements to each element that needed it. Business Model Innovation can be described as follows:

\section{Value Proposition}


In this aspect, bumdes Pagerwangi needs to provide business units that can provide good service, competitive prices, and have a variety of quality products. Currently, if you look at the prices offered by the two business units operating in the Pagerwangi bumdes, it is considered appropriate to the target market, which are residents of the surrounding villages. Researchers found other things that need to be improved to support business model innovation, namely related to service and product quality and diversity. Bumdes need to add human resources, improve the system and increase the services provided to customers. This can be achieved, among others, by establishing service procedures in all business units as well as creating new service systems such as delivery services which can then enable customers to get their needs more easily and quickly. In terms of products, bumdes can be partners with village communities in marketing their own products.

2. Customer Segment

In general, the customer segment chosen by the bumdes is geographical, which focuses on the Pagerwangi area. The selection of this segmentation is actually appropriate considering that in fact bumdes is a facility that can serve the community around where the bumdes is located. However, the Bumdes has the capacity to reach more customers outside its target market so as to increase revenue. If this is to be done, then the bumdes needs to develop its business strategy going forward

\section{Channels}

Bumdes needs to develop a channel or channels that are currently running. Bumdes can use communication facilities such as whatsapp to interact with customers or potential customers as a means of promotion and purchase of bumdes products/services. In addition, bumdes can take advantage of social media or marketplaces to reach more distant customers

\section{Customer Relation}

In this aspect, bumdes pagerwangi needs to start building or forming better, closer, and more intensive relationships with customers. This can be done for example by always applying a smile, greeting, and greeting when dealing with customers. In addition, by giving bonuses or discounts to loyal customers, giving greetings on holidays or birthdays.

\section{Revenue Streams}

To get revenue opportunities that can be maximized, bumdes Pagerwangi can add other business units and develop existing ones. At Minimart, Bumdes can sell basic needs from rural communities such as gas and basic necessities as well as become a place to sell products produced by local residents. Other business units can also be developed such as providing cafes/dining places, renting facilities owned by the village, and being able to provide assistance for products produced by villagers, especially related to marketing.

\section{Key Resource}

Currently, the Pagerwangi bumdes does not yet have adequate resources, particularly in the areas of human resources, intellectual resources, and financial resources. In human resources, Bumdes needs improvements such as implementing a performance management system, one of which is the implementation of performance targets. In addition, the bumdes can make process improvements and procure additional human resources to assist its business processes. From intellectual resources, bumdes need to conduct training and human resource development. Meanwhile, in terms of financial resources, Bumdes Pagerwangi cannot rely solely on the two business units but needs 
to make some improvements and developments to increase its income. For physical resources, the Pagerwangi bumdes already has the facilities and infrastructure to support its business activities such as land and buildings, computers and other shop facilities, and is equipped with a good internet connection..

\section{Key Activities}

In addition to running two business units, the activities carried out at the Pagerwangi bumdes need to be increased in order to develop and increase revenue. This is nothing but the welfare of the bumdes and the village community in general. Activities that can be carried out in the future include business promotion both offline and online, providing merchandise directly from first-hand suppliers, providing delivery services to customers, creating new business units such as cafes or others.

\section{Key Partnership}

The costs incurred by bumdes include operational costs such as employee salaries, electricity, water, internet quota, as well as depreciation costs for buildings and machinery. The current employee payroll system can be improved by, for example, applying a salary based on performance that can be evaluated from the supervisor's assessment or business income.

\section{Conclusion}

The implementation of design thinking can build the innovation of the Bumdes Pagerwangi business model by providing added value to the value proposition elements, key activities and key resources. Bumdes Pagerwangi can implement improvements to systems within its organization first and then apply business model innovations starting with 3 priority BMC elements followed by 6 other elements customer segments, channels, customer relationships, revenue streams, key partners, and cost structure.

\section{References}

[1] Kementerian Keuangan Republik Indonesia, Buku Pintar Dana Desa, November: Kementerian Keuangan Republik Indonesia, 2017.

[2] A. S. Kusuma, „Peranan Badan Usaha Milik Desa (Bumdes) Sebagai Upaya Dalam Meningkatkan Pendapatan Asli Desa (Pades) Serta Menumbuhkan Perekonomian Desa,“ Journal Of Rural And Development, Zv. Volume V No. 1, 2014.

[3] E. Rahmawati, „Analisis Pengelolaan Badan Usaha Milik Desa (Bum Desa) Di Kabupaten Bandung Barat,“ Jurnal Ilmiah Ekonomi Bisnis, Zv. Volume 25 No. 1, April 2020.

[4] Kementerian Desa, Pembangunan Daerah Tertinggal, „Rambah Pasar Digital, Dana Desa Alokasikan Rp4,2 Triliun Modal Bumdes,“ 26 Januari 2021. [Online]. Available: Https://Kemendesa.Go.Id/Berita/View/Detil/3587/Rambah-Pasar-Digital-Dana-Desa-AlokasikanRp42-Triliun-Modal-Bumdes.

[5] Handi, „Berita Daerah,“ Tujuh Provinsi Dengan Bumdes Terbanyak, 30 Juni 2021. [Online]. Available: Https:/Www.Beritadaerah.Co.Id/2021/06/30/Tujuh-Provinsi-Dengan-BumdesTerbanyak/. [Cit. Oktober 2021].

[6] T. A. Saputra, „Implementasi Design Thinking Dalam Membangun Inovasi,“ Agora Jurnal Mahasiswa Manajemen Bisnis Universitas Kristen Petra, Zv. Vol. 4 No. 1, Pp. 833-844, 2016.

[7] A. S. Hussein, Metode Design Thinking Untk Inovasi Bisnis, Malang: Tim Ub Press, 2018. 